\title{
MENGEMBANGKAN POTENSI DESA WISATA TENUN MELALUI KEGIATAN NTOBO FASHION WEEK
}

\author{
${ }^{1 *}$ Ita Purnama, ${ }^{2}$ Irma Mardian, ${ }^{3}$ Syabahul Khair, ${ }^{4}$ Nuristiqamah, \\ ${ }^{5}$ Nurayu Syafitri \\ Manajemen, Sekolah Tinggi Ilmu Ekonomi Bima, Indonesia \\ Email : ${ }_{\text {ita123purnama@gmail.com }}$
}

Manuskrip: Desember -2021; Ditinjau: Desember -2021; Diterima: Januari -2022; Online: Januari-2022; Diterbitkan: Januari-2022

\begin{abstract}
ABSTRAK
Minimnya pengetahuan akan metode promosi produk pada UMKM kelurahan ntobo merupakan salah satu indikator dasar hadirnya kegiatan NTOBO FASHION WEEK yang dimana membantu mendorong pemahaman masyarakat akan beragamnya metode pemasaran dalam memperkenalkan produk di UMKM kelurahan ntobo itu sendiri, selain itu hadirnya kegiatan ini sebagai salah satu suplai ide untuk mendorong masyarakat ntobo dalam hal promosi barang lokal. Dengan adanya kegiatan NTOBO FASHION WEEK bertujuan memberikan suplai semangat kepada masyarakat NTOBO sehingga gairah masyarakat dalam mengembangkan inovasi produk dapat tumbuh kembali, selain itu kegiatan NTOBO FASHION WEEK menjadi salah satu bukti fisik yang memberikan nilai edukasi kepada masyarakat, bahwa dalam memperkenalkan produk tenunan NTOBO memerlukan perjuangan,kreativitas dan semangat yang tinggi sehingga produk tenunan NTOBO dapat bersaing dengan produk berskala nasional maupun internasional.
\end{abstract}

\section{Kata Kunci: Ntobo Fashion Week, Promosi Produk}

\section{PENDAHULUAN}

Kelurahan NTOBO adalah kelurahan yang di tetapkan oleh pemerintah sebagai salah satu kelurahan pariwisata yang ada di KOTA BIMA, yang dimana memfokuskan pada wisata tenunan dan memiliki 4 UMKM dan 90\% ibu rumah tangga ber profesi sebagai penenun. sebagai daerah wisata, tentunya kelurahan NTOBO memerlukan banyak sekali perubahan dan penataan, baik dalam bentuk penataan sarana dan prasarana, sehingga penetapan sebagai daerah wisata tidak hanya sebagai kata penghias saja.

Dilihat dari kondisi objektiv kelurahan NTOBO banyak sekali menemukan permasalahan dalam hal memenuhi persaratan sebagai desa wisata, dimana yang paling mencolok adalah pada bagian proses perkenalan produk tenunan pada halayak luas. Hal ini tentu di pengaruhi oleh budaya masyarakan yang masih minim akan pengetahuan mengenai penggunaan metode dalam memperkenalkan produk NTOBO itu sendiri baik dalam memanfaatkan media sosial maupun dalam bentuk 
lain nya, Sehingga produk tenunan NTOBO menemui kesulitan untuk menembus pasar nasional dan internasional, adapun permasalahan lain yang sering di temui yaitu, minim nya minat dan semangat dalam menjeput hal baru dalam pengembangan metode memperkenalkan prduk sehingga kemajuan informasi maupun pelaksanaannya bersifat mekanis.

Dengan adanya kegiatan NTOBO FASHION WEEK bertujuan memberikan suplai semangat kepada masyarakat NTOBO sehingga gairah masyarakat dalam mengembangkan inovasi produk dapat tumbuh kembali, selain itu kegiatan NTOBO FASHION WEEK menjadi salah satu bukti fisik yang memberikan nilai edukasi kepada masyarakat, bahwa dalam memperkenalkan produk tenunan NTOBO memerlukan perjuangan,inovasi,kreativitas dan semangat yang tinggi sehingga produk tenunan NTOBO dapat bersaing dengan produk berskala nasional maupun internasional.

\section{MASALAH}

Wilayah kelurahan NTOBO adalah tempat pelaksanaan kegiatan NTOBO FASHION WEEK yang merupakan wilayah yang memiliki produk yang unggul yaitu tenun yang dimana Ntobo juga dikenal dan mendapat julukan sebagai desa wisata tenun. Namun dibalik keunggulannya tersebut,ada beberapa hal yang menjadi hambatan di kelurahan Ntobo untuk memperkuat dalam memperkenalkan produk tenunannya, salah satunya adalah keterbatasan pengetahuan masyarakat dalam hal mempromosikan produk tenunan secara luas menjadikan kegiatan NTOBO Fashion Week ini diadakan. Dan juga letak kelurahan NTOBO yang jauh dari jantung kota menjadi salah satu alasan jelas akan keterlambatan mendapatkan informasi terakrual dalam hal memperkenalkan produknya baik dalam pemanfaatan media sosial, pelaksanaan kegiatan berbasis promosi maupun pengetahuan engenai global marketing yang tentunya memberikan dampak positif bagi masyarakat berkaitan dengan pemahaman memperkenalkan produk tenun kelurahan NTOBO di masyarakat luas, Menurut Sugiyono (2009:52) masalah diartikan sebagai penyimpangan antara yang seharusnya dengan apa yang benar-benar terjadi, antara teori dengan praktek, antara aturan dengan pelaksanaan, antara rencana dengan pelaksana.

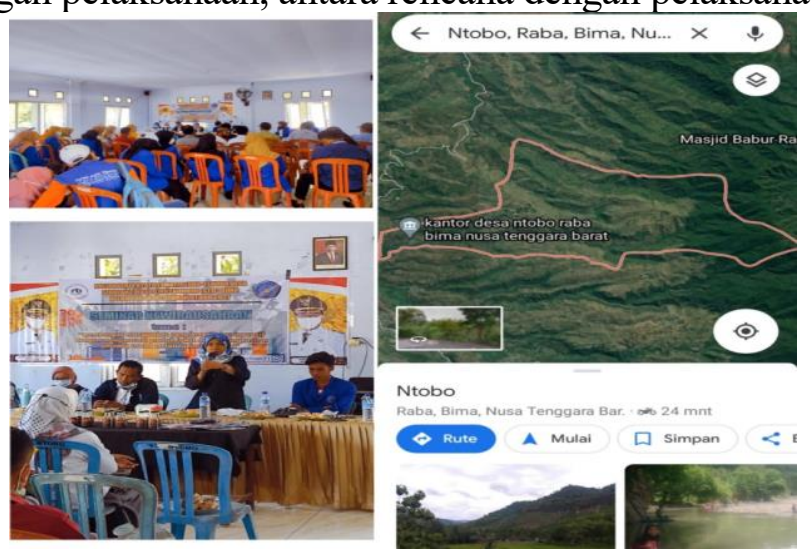

Gambar 1. Peta kegiatan pengabdian kepada masyarakat sekaligus pemaparan perencanaan kegiatan NTOBO FASHION WEEK 


\section{PERSIAPAN}

Tahap persiapan dari kegiatan ini adalah pembuatan panflet dan pengurusan administratif dan penempatan tempat kegiatan yang di lakukan di lapangan volly kelurahan NTOBO, serta penentuan konsep kegiatan dan layout yang nantinya menjadi konsep kegiatan, serta tidak lupa pula penentuan waktu pelaksanaan dan rundown acara selain itu persiapan peralatan dan perlengkapan serta pendataan peserta adalah hal yang tidak kalah penting pula.

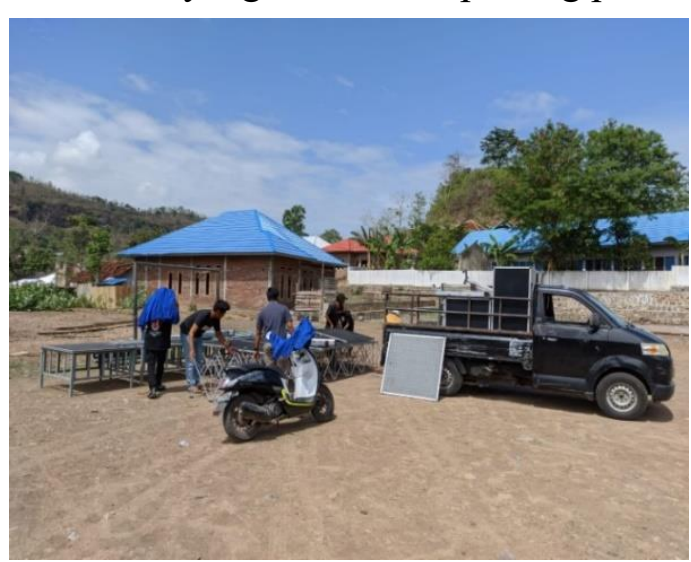

Gambar 2. Proses Persiapan Panggung

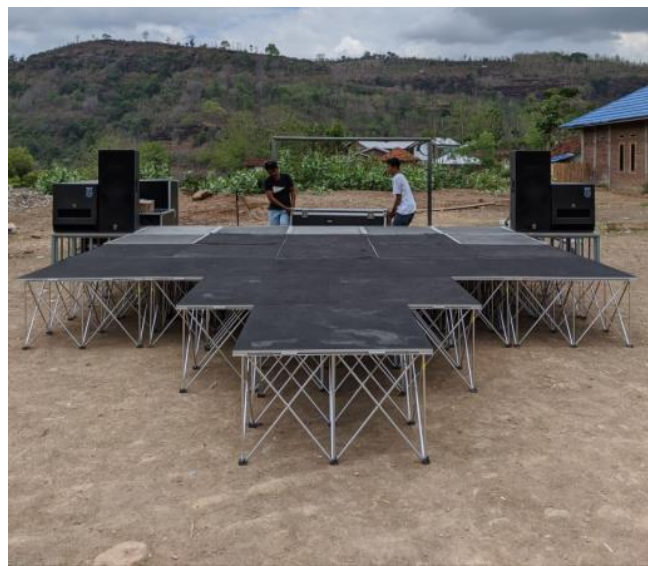

Gambar 3. Proses Penyelesaian Panggung

\section{PROSES DAN PELAKSANAAN}

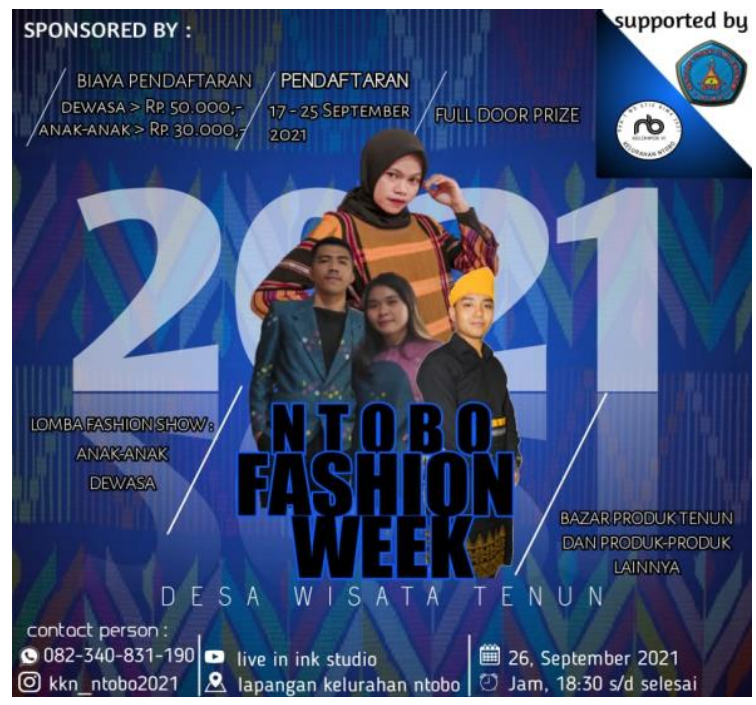

Gambar 4. Brosur Ntobo Fashion Week

Tahap pelaksanaan kegiatan ini di awali dengan gladi bersih di mana semua peserta akan melakukan pengetesan jalan lalu kegiatan dimulai pada pukul 17.00 s/d 22.00 WITA .sesuai dengan jadwal yang di tentukan, dan pelaksanaan kegiatan berjalan sesuai dengan rundown yang di susun oleh kepanitiaan seperti dibawah ini: 
1. Pembukaan

2. Persembahan tari dari sanggar doro to'i

3. Penandatanganan MOU oleh Rektor Sekolah Tinggi Ilmu Ekonomi (STIE) Bima dan BAPAK LURAH NTOBO

4. FASHION SHOW tingkat anak-anak

5. Musikalisasi

6. FASHION SHOW tingkat dewasa

7. pembagian juara

8. Penutup

Dan setelah penutupan secara resmi dan acara selanjutnya di akhiri dengan ucapan panitia pelaksana kepada masyarakat dan jajaran kelurahan dan di akhiri dengan foto bersama panitia pelaksana.

\section{EVALUASI}

Peserta yang mendaftar sebanyak 30 orang anak-anak yang mengikuti fashion kategori anak dan 30 orang dewasa yang mengikuti fashion show kategori dewasa dan ikut di hadiri oleh:

1. Rektor sekolah tinggi ilmu ekonomi bima bersama dengan keluarga

2. Bapak lurah ntobo dan jajaran

3. Ketua karang taruna beserta jajaran

4. Babinsa dan babinkantinmas

5. Kepala dinas pariwisata

6. Jajaran dinas BPOM

7. Serta di hadiri oleh masyarakat dan pemuda kelurahan ntobo

Setting tempat sudah sesuai dengan rencana yang di buat dan perlengakapan untuk kegiatan sudah tersedia pada waktu yang tepat dan sudah di gunakan sebagai mana mestinya. Pengunaan bahsa yang di ginakan pun sangat komunikatif sehingga audiens memahami dan menerimanya dengan baik. Semua penyediaan meja tamu sudah terisi dengan rapi sesuai skejul acara dan semua stand bazar terpenuhi dan di isi oleh kelompok UMKM dan kelompok KKN sesui dengan konsep awal.

\section{HASIL DAN PEMBAHASAN}

Pelaksanaan kegiatan NTOBO FASHION WEEK ini di laksanakan pada tanggal 25 September 2021 di lapangan sepak bola Kelurahan Ntobo, Kecamatan Rasa Nae Barat, Kota Bima dengan metode pelaksanaan kegiatan yang dimulai dengan pengenalan produk tenun karya masyarakat kelurahan ntobo baik berupa bazar maupun fashion show tenunan hasil karya designer Ntobo dan di lanjutkan dengan lomba fashion show yang di ikuti oleh tingkat anak anak dan dewasa yang dimana peserta bukan hanya ruang lingkup kota bima saja akan tetapi di ikuti juga oleh beberapa delegasi dari kabupaten Bima, selain itu dikegiatan ini juga di adakan 
kegiatan penandatanganan MOU Kerjasama antara STIE BIMA dan kelurahan ntobo yang dimana langsung di tanda tangani oleh lurah

Ntobo dan rektor STIE BIMA yang berguna untuk kelanjutan pembinaan UMKM - UMKM yang ada di Ntobo untuk menginovasi produk maupun kegiatan pembinaan lainnya. Selanjutnya dalam kegiatan lomba fahion show tenunannya terdapat pemenang lomba yang dalam kegiatan ini berjumlah tiga orang dengan juara 1,2, dan 3 peserta dari tingkat anak-anak dan berjumlah tiga orang dengan juara 1,2, dan 3 peserta dari tigkat dewasa, Pelaksanaan kegiatan NTOBO FASHION WEEK bertujuan memperkenalkan tenunan ntobo kepada masyarakat luas, selain itu kegiatan NTOBO FASHION WEEK di tujukan sebagai bahan edukasi bagi masyarakat supaya harapan nya akan ada kegiatan sejenis bahkan lebih yang akan di bangun di kemudian hari. Media dan alat yang di sediakan berupa panggung, sound sistem, stand bazar metode yang di gunakan adalah metode FASHION SHOW standar nasional, pementasan musik dan hiburan lain serta penanda tanganan surat perjanjian kerja sama.

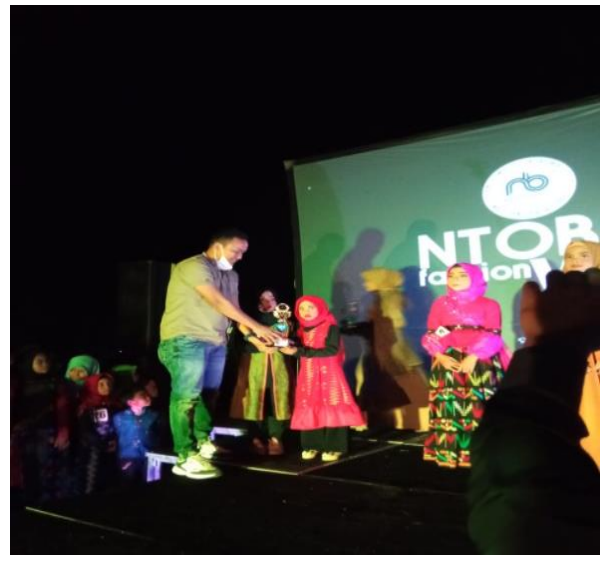

Gambar 9. Penyerahan hadiah kepada kategori anak-anak

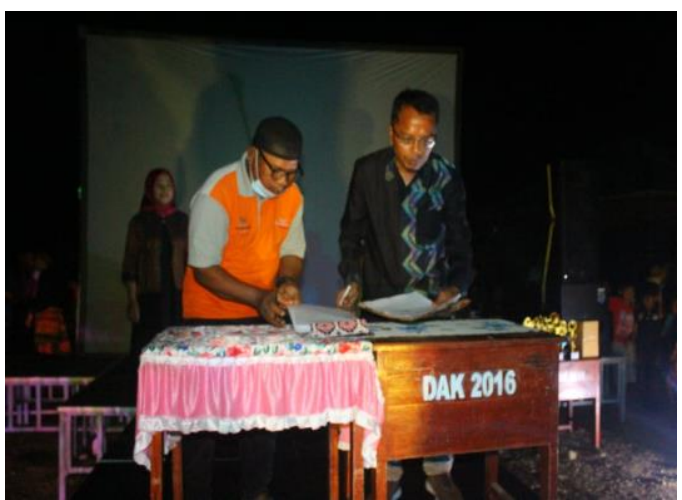

Gambar 7. penandatanganan MOU atau penetapan kelurahan ntobo sebahai

Kelurahan binaan,antara ketua Lembaga sekolah tinggi ilmu ekonomi bima dan bapak lurah ntobo

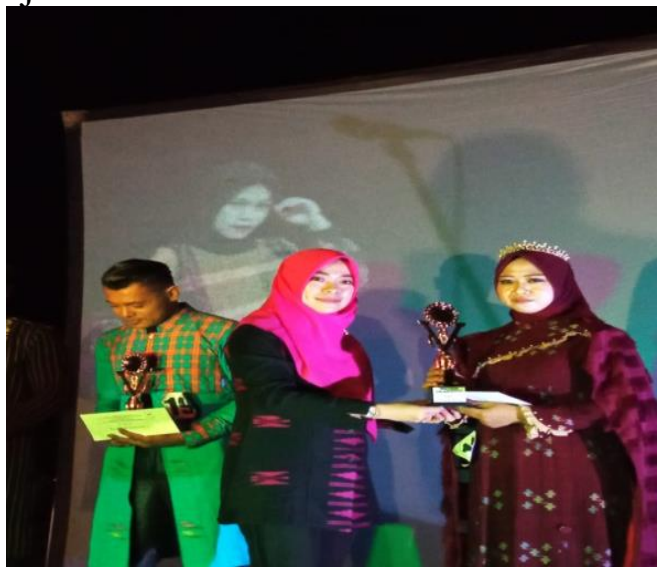

Gambar 6. penyerahan hadiah kepada peserta kategori dewasa

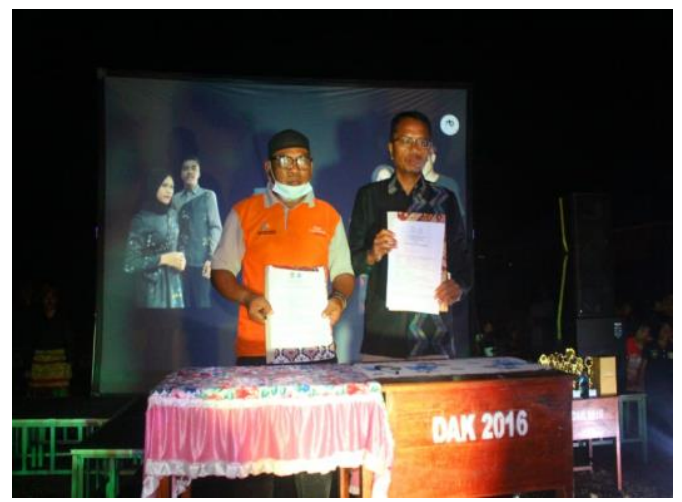

Gambar 8. proses dokumentasi hasil penandatanganan MOU 


\section{KESIMPULAN}

Produk tenunan adalah salah satu item yang menjadi sorotan yang memiliki khas tersendiri yang berada di kelurahan NTOBO dan tentunya itu yang menjadi item penting untuk kota bima sehingga harus banyak pihak yang saling bergandengan tangan dan banyak membuka pikiran demi terealisasinya prodak tenunan yang di kenal di nasional maupun inter nasional walaupun seperti yang kita tau sudah beberapa kali produk tenunan bima di kenal di nasional dan inter nasional, akan tetapi itu bukan salah satu pijakan yang kuat untuk masarakat bima dan Khususnya masyarakat kelurahan NTOBO untuk bernafas lega dan merasa puas. Hadirnya kegiatan NTOBO FASHION WEEK sebagai salah satu metode dalam memperkenalkan tenunan NTOBO dengan harapan dapat membuka ruang pandang dan berpikir bagi msayarakat bima pada umumnya dan masyarakat ntobo pada khususnya, sehingga kegiatan seperti ini dapat memiliki keberlanjutan dan bersifat continue sehingga selain prodak tenunan yang bisa membuming juga dapat menambah penghasilan masyarakat setempat secara finansial.

\section{DAFTAR PUSTAKA}

A . Riyanto, Arifah . 2003 . Teori Busana. Bandung : Yapemdo

Andrina Arlini. 2007. "Skripsi Fashion Center Of Kebaya di Yogyakarta". Atma Jaya Yogyakarta

https://harpersbazaar.co.id/articles/read/10/2015/1814/jurnal-editor-fashion-week.

Di akses 01 November 2021.

Id.wikihow.com/Mengadakan-Peragaan-Busana. Di akses 01 November 2021

Karmiyanti , C . Y. 2018 . Penciptaan Peragaan Busana "Aksara Warna . Yogyakarta, Institut Seni Indonesia Yogyakarta

Nawawi, Hadari. (2008). Manajemen Sumber Daya Manusia Untuk Bisnis yang Kompetitif, cetakan keempat. Yogyakarta : Gadjah Mada University Press. Noor, Any. (2009). Manajemen Event. Bandung: Alfabeta.

Nurjaya, N., et al. (2021). The Effect of Product Promotion and Innovation Activities on Marketing Performance in Middle Small Micro Enterprises in Cianjur. Budapest International Research and Critics Institute (BIRCIJournal): Humanities and Social Sciences, 4(1), 528-540.

Ruslan, Rosady. (2010). Manajemen Public Relations dan Media Komunikasi:Konsepsi dan Aplikasi. Jakarta: RajaGrafindo Persada. 